\title{
Investigation of relationship between smartphone addiction and internet addiction in working children in industry
}

\author{
Emriye Hilal Yayan ${ }^{1}$ \\ Yeliz Suna Dağ \\ Mehmet Emin Düken ${ }^{3}$ \\ Ayşegül Ulutaş ${ }^{4}$
}

\begin{abstract}
Aim: The aim of the study was conducted to examine the relationship between smartphone addiction and internet addiction of working children in industry.

Material and Method: This research was carried out with 183 children working at various work places in Diyarbakır province center between January and March 2017 as a descriptive relational. Child Information Form, Young Internet Addiction Scale and Smart Phone Dependence Scale were used in the study. The data were collected by face-to-face interview technique.

Results: According to the statistical results of the study group, the average age of the students participating in the study was $14.53 \pm 2.08$. The average Internet and smartphone addiction scores of children whose mother were not alive $(p=0.000)$ or whose father $(p=0.000)$ were not alive and whose internet use was not supported $(p=0.000)$ were found to be higher. The mean scores of the groups were found to be significantly different. The mean internet and smart phone addiction scores of the children who worked well with the master at work $(p=0.000, p=0.035)$ were found to be low and there was a significant difference between the groups. Children who were exposed to violence in the work environment $(\mathrm{p}=0.000)$ are quite high internet and smart phone addiction scores and the difference between the groups was found to be significant. It had founded that the children who use smart phone and internet for fun $(p=0.001, p=0.002)$, chatting $(p=0.005)$ and browsing sites $(\mathrm{p}=0.038, \mathrm{p}=0.001)$ was higher phone addiction and internet addiction scores. It was determined that there was a meaningful difference between the average scores

Conclusion: Working children showed high internet and smart phone addiction behaviors, this resulted from originated family and social environment.
\end{abstract}

Keywords: Working child; internet addiction; smart phone dependency.

\footnotetext{
1 Assistant Professor Inönü University Nursing Faculty Child Health and Disease Nursing Department, emriye.yayan@inonu.edu.tr

2 Research Assistant Inönü University Nursing Faculty Child Health and Disease Nursing Department, yeliz.suna@inonu.edu.tr

3 Research Assistant Inönü University Nursing Faculty Child Health and Disease Nursing Department, emin.duken@inonu.edu.tr

4 Assistant Professor Inönü University School of Health Sciences Department of Child Development, aysegul.ulutas@inonu.edu.tr
} 
Yayan, E. H., Dağ, Y. S., Düken, M. E., \& Ulutaş, A. (2019). Investigation of relationship between smartphone addiction and internet addiction in working children in industry. Journal of Human Sciences, 16(1), 143-154. doi:10.14687/jhs.v16i1.5397

\section{Introduction}

The concept of working children is defined as the involvement of children under the age of 18 in work life to maintain their lives or to contribute to the family budget (Fidan, 2004). Although poverty and unfair income distribution are the most basic reasons for child labor, the cultural structure, education level of the family, fragmentation of family, migration and population growth, lack of educational opportunities, unemployment, cheap labor force requirements of employers, inadequate labor regulations and failure in implementation of labor laws are also among the reasons of this fact (Aksakal, 2016; Gol, 2016; Tor, 2010).

According to the ILO's records, 306 million (19.3\%) of the 1,586 billion children in the world are in the employment sector and 250 million (about 70\%) are child workers, which means that one in every seven children is a child worker. Of these children, 115 million undertake very dangerous tasks (ILO, 2010). According to the 2012 data of Turkey Statistical Institute, the child population in the $0-17$ age range constitute $30 \%$ of the total population (Yildirim, Beydili, \& Görgülü, 2015). This negatively affects the health of children, hinder their physical, cognitive, social and emotional development prevent them continue their education, and since they are very young, they are exposed to hazards caused by mental, physical, chemical and environmental factors, suffer from inadequate and unbalanced nutrition, as well as physical, emotional and sexual abuse and neglect. Therefore, the working children become ill-tempered, withdrawn, insecure and incompatible with their surroundings; in addition, they lack social security, work with low wages, and may acquire bad habits and addictions such as smoking, alcohol and even drugs in working environments (Agbo, 2017; Gol, 2016; İşeri et al., 2005; Tor, 2010).

The use of the Internet and smartphones has recently became an essential tool for information, entertainment and social communication. It has been widely adopted as a low cost, easy to access platform for social interaction and leisure activities, especially by adolescents (Tsitsika et al., 2016). However, this has become a social problem today (Kim, Lee, Lee, Nam, \& Chung, 2014; Kwon et al., 2013; Lee \& Lee, 2017; Nie, Zhang, \& Liu, 2017).

According to data provided by the Turkey Statistical Institute (TÜIK, 2011), Internet use in the 16-74 age group is $69.6 \%$ in Turkey, and Turkey ranks 15th among the countries with the most Internet users in the world (IWS, 2017). Internet and smartphone addiction is defined as the failure to control increased use of Internet and smartphone as to cause potential harm to individuals' life (Gunuc \& Dogan, 2013; Ko, Yen, Yen, Chen, \& Chen, 2012; Morahan-Martin \& Schumacher, 2000; Tang et al., 2014).

The problems associated with Internet and smartphone addiction generally include mood disorders, disruptive behavior disorders, anxiety disorders, sleep disorders, nutritional disorders, anxiety disorders, attention deficit and hyperactivity disorder, depression, loneliness, tendency to violence, social isolation, decreased work performance and school achievement, low self-esteem, musculoskeletal diseases, extreme fatigue, eye diseases and mental disorders(Luparenko, 2014; Şata, Çelik, Eetürk, \& Taş, 2016; Tahiroğlu, Çelik, Bahalı, \& Avcı, 2010; Ülgen, 2014).

Purpose: This study was conducted to investigate the relationship between smartphone addiction and Internet addiction in working children in industry.

\section{Method}

\section{Research Design}

This research is a relational descriptive type research.

\section{Sample of the Study}

This study was carried out between January-March 2017 by obtaining the legal permissions from Diyarbakır Governorate and ethical approval from the İnönü University Health Sciences Non-Interventional Clinical Research and Publication Ethics Committee. No sampling 
Yayan, E. H., Dağ, Y. S., Düken, M. E., \& Ulutaş, A. (2019). Investigation of relationship between smartphone addiction and internet addiction in working children in industry. Journal of Human Sciences, 16(1), 143-154. doi:10.14687/jhs.v16i1.5397

method was applied. All children working in the industrial center of Diyarbakir, who met the research criteria and accepted the study were included in the study. After obtaining the necessary permits, the children working in the industry in Diyarbakir received written permission firstly. Data were collected by face-to-face interviews with each child. Data collection was completed for a period of approximately 6 months. Data from each child took 20 minutes to collect.

\section{Research criteria}

Criteria of the study consisted of the fact that the child is older than 12 years, has a smart phone and plays in the industrial zone.

\section{Data Collection Instruments}

The study data were collected with the Children Information Form, the Young Internet Addiction Scale and the Smartphone Addiction Scale using face-to-face interview method.

Children Information Form: It consists of 33 items about age, gender, education, and place of residence of the children to determine their socio-demographic characteristics.

Young Internet Addiction Scale (IAS): The 5-point Likert type YIAS-SF, developed by Young and transformed into short form by Pawlikowski et al., consists of 12 items (scored between $1=$ Never, $5=$ Always). The internal consistency reliability coefficient of the scale was calculated to be 0.85 . There is no reverse-scored items in the scale. Higher scores of the scale indicate a higher level of Internet addiction (Kutlu, Savci, Demir, \& Aysan, 2016).

Smartphone Addiction Scale (SAS): The smartphone addiction scale has been developed by Kwon $\mathrm{M}$ et al. The 6-point Likert-type scale consists of 33 items (scored as $1=$ Strongly disagree, $2=$ Disagree, $3=$ Weakly disagree, $4=$ Weakly agree, $5=$ Agree, $6=$ Strongly agree). The lowest score to be taken by marking Strongly disagree in all items is 33, and the highest score is 198, which is taken by marking Strongly yes in all items. The scale itself consists of seven factors. Factor 1 "daily-life disturbance and tolerance" consists of 8 items $(1,2,5,29,30,31,32,33)$, Factor 2 "withdrawal symptoms" consists of 7 items (10, 11, 12, 13, 14, 15, 16), Factor 3 "positive anticipation" consists of 5 items $(6,7,8,9,20)$, Factor 4 "cyberspace-oriented relationship" consists of 4 items $(21,22,23,26)$, Factor 5 "overuse" consists of 4 items $(17,18,19,28)$, Factor 6 "social network addiction" consists of 2 items $(24,25)$ and Factor 7 "physical symptoms" consists of 3 items $(3,4,27)$. There is no threshold point in this scale. However, the increasing scores on the test indicate increasing risk for addiction. The Cronbach's alpha internal consistency coefficient of the scale is 0.947 (Demirci, Orhan, Demirdas, Akpinar, \& Sert, 2014).

\section{Research Analysis}

SPSS 22.0 program was used for statistical analysis. The normal distribution of the data were analyzed using analytical methods (Kolmogorov-Smirnov/Shapiro-Wilk tests). Since the study data meet the parametric conditions, Student's t test was used and One-Way ANOVA was used for the comparison of three or more groups. Data were presented as arithmetic mean \pm standard deviation. Pearson correlation analysis test was used for correlation analysis since both variables have a normal distribution. $\mathrm{P}<0.05$ was accepted as the level of statistical significance. 
Yayan, E. H., Dağ, Y. S., Düken, M. E., \& Ulutaş, A. (2019). Investigation of relationship between smartphone addiction and internet addiction in working children in industry. Journal of Human Sciences, 16(1), 143-154. doi:10.14687/jhs.v16i1.5397

\section{Results}

Table 1. Some Demographic Characteristics of Working Children in industry

\begin{tabular}{lll}
\hline & $\mathbf{n}$ & \\
\hline Gender & & 15.3 \\
Female & 28 & 84.7 \\
\hline Male & 155 &
\end{tabular}

Child's educational status

Doesn't go to school (at the school age)

$24+13.1$

\begin{tabular}{lll}
\hline Primary school & 21 & 11.5 \\
\hline Secondary School & 98 & 53.6 \\
\hline High School & 40 & 21.9 \\
\hline
\end{tabular}

\begin{tabular}{lll}
\hline Use of protective equipment at work & & \\
Yes & 13 & 7.1 \\
\hline No & 170 & 92.9 \\
\hline
\end{tabular}

Relationship with the master at the workplace

\begin{tabular}{lll} 
Good & 58 & 31.7 \\
\hline Medium & 79 & 43.2 \\
\hline Poor & 46 & 25.1 \\
\hline $\begin{array}{l}\text { Paternal vital status } \\
\text { Yes }\end{array}$ & 112 & 61.2 \\
\hline No & 71 & 38.8 \\
\hline Maternal Vital Status & 138 & 75.4 \\
Yes & 45 & 24.6 \\
\hline No & & \\
\hline Have you exposed to violence? & 97 & 53.0 \\
Yes & 86 & 47.0 \\
\hline No & 35 & 19.1 \\
\hline Supervised Internet Usage Status & 80.9 \\
Yes & 148 & \\
\hline No & & \\
\hline
\end{tabular}

According to the statistical analysis results of the study group, the average age of the students participating in the study was $14.53 \pm 2.08$ and $84.7 \%$ of them was male and $15.3 \%$ was female. It was found that $13.1 \%$ of the children was not going to school, $92.9 \%$ was not using protective equipment at the workplace and $25.1 \%$ had bad relations with the masters at workplace. Of the children participating in the study, 38.8\% had no living father, $24.6 \%$ had no living mother, $10.9 \%$ had unemployed father, and $71.6 \%$ had unemployed mother.

Of the children, $94 \%$ goes to Internet cafes regularly, $85.2 \%$ use the Internet regularly, $80.9 \%$ uses unsupervised Internet, and $95.6 \%$ use the Internet for entertainment purposes and $32.2 \%$ for education purposes.

The average weekly working hours of the children participating in the study was $36.63 \pm 14.90$, their average monthly income was $550.05 \pm 305.81$, the average phone price used was $726.55 \pm 420.05$, average daily time spent in Internet cafe was $3.86 \pm 1.36$ hours, and the average monthly income of their families was $1488.10 \pm 530.27$ (Table 1). 

Journal of Human Sciences, 16(1), 143-154. doi:10.14687/jhs.v16i1.5397

Table 2. Comparison of IAS, SAS Scores and Some Demographic Characteristics of Working Children in industry

\begin{tabular}{|c|c|c|c|c|c|c|c|c|c|c|}
\hline & & Tolerance & $\begin{array}{l}\text { Withdrawal } \\
\text { symptoms }\end{array}$ & $\begin{array}{l}\text { Positive } \\
\text { anticipation }\end{array}$ & $\begin{array}{l}\text { Cyberspace- } \\
\text { oriented } \\
\text { relationship }\end{array}$ & Overuse & $\begin{array}{l}\text { Social } \\
\text { network } \\
\text { addiction }\end{array}$ & $\begin{array}{l}\text { Physical } \\
\text { symptoms }\end{array}$ & $\begin{array}{l}\text { Phone } \\
\text { addiction }\end{array}$ & $\begin{array}{l}\text { Internet } \\
\text { Addiction }\end{array}$ \\
\hline \multirow{4}{*}{$\begin{array}{l}\text { Paternal } \\
\text { status }\end{array}$} & Yes & $31.24 \pm 11.25$ & $26.21 \pm 9.82$ & $19.68 \pm 6.89$ & $15.12 \pm 18.64$ & $15.51 \pm 5.71$ & $7.97 \pm 3.19$ & $11.90 \pm 3.99$ & $127.67 \pm 45.39$ & $33.66 \pm 10.64$ \\
\hline & No & $38.21 \pm 2.91$ & $32.94 \pm 3.01$ & $23.49 \pm 2.46$ & $18.64 \pm 2.26$ & $19.60 \pm 0.93$ & $9.90 \pm 0.83$ & $14.11 \pm 1.60$ & $156.91 \pm 11.50$ & $53.92 \pm 0.64$ \\
\hline & T value* & 5.108 & 5.599 & 4.470 & 4.747 & 5.972 & 4.980 & 4.439 & 5.315 & 14.856 \\
\hline & $\mathrm{p}$ & 0.000 & 0.000 & 0.000 & 0.000 & 0.000 & 0.000 & 0.000 & 0.000 & 0.000 \\
\hline \multirow{4}{*}{$\begin{array}{l}\text { Maternal } \\
\text { status }\end{array}$} & Yes & $32.65 \pm 10.53$ & $27.25 \pm 9.17$ & $20.20 \pm 6.32$ & $15.52 \pm 5.51$ & $16.29 \pm 5.31$ & $8.36 \pm 2.96$ & $12.33 \pm 3.77$ & $132.63 \pm 42.13$ & $36.97 \pm 11.84$ \\
\hline & No & $37.88 \pm 3.78$ & $33.64 \pm 3.04$ & $24.11 \pm 2.76$ & $19.48 \pm 1.67$ & $19.57 \pm 2.02$ & $9.82 \pm 1.19$ & $14.06 \pm 1.58$ & $158.60 \pm 14.32$ & $55.48 \pm 6.04$ \\
\hline & T value* & 3.257 & 4.583 & 4.018 & 4.738 & 4.042 & 3.213 & 2.992 & 4.051 & 10.050 \\
\hline & $\mathrm{p}$ & 0.001 & 0.000 & 0.000 & 0.000 & 0.000 & 0.002 & 0.003 & 0.000 & 0.000 \\
\hline \multirow{4}{*}{$\begin{array}{l}\text { Supervised } \\
\text { internet usage } \\
\text { status }\end{array}$} & Yes & $28.20 \pm 11.51$ & $23.60 \pm 10.40$ & $18.00 \pm 7.50$ & $14.45 \pm 6.23$ & $14.00 \pm 6.18$ & $7.25 \pm 3.40$ & $11.02 \pm 4.23$ & $116.54 \pm 47.57$ & $29.80 \pm 5.86$ \\
\hline & No & $35.30 \pm 8.58$ & $30.06 \pm 7.58$ & $21.91 \pm 5.20$ & $16.98 \pm 4.75$ & $17.83 \pm 4.27$ & $9.06 \pm 2.40$ & $13.16 \pm 3.11$ & $144.33 \pm 34.63$ & $44.30 \pm 13.12$ \\
\hline & T value* & 4.107 & 4.196 & 3.647 & 2.658 & 4.347 & 3.668 & 3.397 & 3.953 & 6.376 \\
\hline & p & 0.000 & 0.000 & 0.000 & 0.000 & 0.000 & 0.000 & 0.000 & 0.000 & 0.000 \\
\hline \multirow{5}{*}{$\begin{array}{l}\text { Relationship } \\
\text { with the } \\
\text { master at the } \\
\text { workplace }\end{array}$} & Good & $30.96 \pm 10.60$ & $26.36 \pm 9.27$ & $20.18 \pm 6.57$ & $15.72 \pm 6.01$ & $15.31 \pm 5.16$ & $8.13 \pm 2.98$ & $11.84 \pm 3.86$ & 128.53 & $30.20 \pm 6.01$ \\
\hline & Medium & $35.02 \pm 9.64$ & $29.50 \pm 8.16$ & $21.18 \pm 5.74$ & $16.51 \pm 4.74$ & $17.67 \pm 4.83$ & $8.89 \pm 2.66$ & $13.22 \pm 3.37$ & $142.03 \pm 37.92$ & $45.43 \pm 12.33$ \\
\hline & Poor & $35.84 \pm 7.18$ & $30.76 \pm 7.70$ & $22.34 \pm 5.11$ & $17.45 \pm 4.53$ & $18.39 \pm 4.14$ & $9.15 \pm 2.34$ & $13.10 \pm 2.79$ & $147.06 \pm 32.57$ & $49.10 \pm 12.69$ \\
\hline & T value** & 4.356 & 3.954 & 1.733 & 1.461 & 6.292 & 2.114 & 3.074 & 3.420 & 47.925 \\
\hline & p & 0.014 & 0.021 & 0.180 & 0.235 & 0.002 & 0.124 & 0.049 & 0.035 & 0.000 \\
\hline \multirow[t]{6}{*}{$\begin{array}{l}\text { Educational } \\
\text { status }\end{array}$} & $\begin{array}{l}\text { Doesn't go } \\
\text { to school }\end{array}$ & 10 & $31.12 \pm 8.25$ & $2.37 \pm 5.49$ & $17.62 \pm 5.04$ & $18.12 \pm 4.39$ & $9.00 \pm 2.50$ & $13.79 \pm 3.12$ & $148.50 \pm 36.04$ & $51.83 \pm 11.00$ \\
\hline & $\begin{array}{l}\text { Primary } \\
\text { school }\end{array}$ & $36.71 \pm 6.68$ & $.23 \pm 5.65$ & $3.09 \pm 4.39$ & $18.38 \pm 3.55$ & $18.47 \pm 3.45$ & $9.61 \pm 1.74$ & $13.76 \pm 2.58$ & $151.28 \pm 27.26$ & $41.66 \pm 11.66$ \\
\hline & $\begin{array}{l}\text { Secondary } \\
\text { School }\end{array}$ & $33.29 \pm 10.59$ & $28.58 \pm 8.87$ & $20.43 \pm 6.42$ & $16.04 \pm 5.18$ & $17.02 \pm 5.33$ & $8.61 \pm 2.88$ & $12.39 \pm 3.77$ & $136.38 \pm 41.91$ & $43.88 \pm 12.92$ \\
\hline & High School & $32.57 \pm 8.83$ & $26.77 \pm 8.84$ & $21.20 \pm 5.24$ & $15.97 \pm 5.62$ & $15.97 \pm 4.65$ & $8.35 \pm 2.77$ & $12.50 \pm 3.04$ & $133.35 \pm 36.75$ & $29.50 \pm 6.93$ \\
\hline & T value** & 1.568 & 1.956 & 1.598 & 1.736 & 1.615 & 1.155 & 1.765 & 1.622 & 22.473 \\
\hline & p & 0.199 & 0.122 & 0.191 & 0.161 & 0.188 & 0.328 & 0.155 & 0.186 & 0.000 \\
\hline
\end{tabular}


Yayan, E. H., Dağ, Y. S., Düken, M. E., \& Ulutaş, A. (2019). Investigation of relationship between smartphone addiction and internet addiction in working children in industry. Journal of Human Sciences, 16(1), 143-154. doi:10.14687/jhs.v16i1.5397

Table 2. Comparison of IAS, SAS Scores and Some Demographic Characteristics of Working Children in industry (continued)

\begin{tabular}{|c|c|c|c|c|c|c|c|c|c|c|}
\hline & & Tolerance & $\begin{array}{l}\text { Withdrawal } \\
\text { symptoms }\end{array}$ & $\begin{array}{c}\text { Positive } \\
\text { anticipation }\end{array}$ & $\begin{array}{l}\text { Cyberspace- } \\
\text { oriented } \\
\text { relationship } \\
\end{array}$ & Overuse & $\begin{array}{c}\text { Social } \\
\text { network } \\
\text { addiction } \\
\end{array}$ & \begin{tabular}{|c|} 
Physical \\
symptoms
\end{tabular} & $\begin{array}{l}\text { Phone } \\
\text { addiction }\end{array}$ & $\begin{array}{l}\text { Internet } \\
\text { Addiction }\end{array}$ \\
\hline \multirow[t]{4}{*}{ Education } & Yes & $33.06 \pm 9.63$ & $28.01 \pm 8.50$ & $21.44 \pm 5.96$ & $16.79 \pm 5.39$ & $16.38 \pm 4.93$ & $8.40 \pm 2.93$ & $12.69 \pm 3.22$ & $136.81 \pm 39.15$ & $29.89 \pm 5.84$ \\
\hline & No & $34.36 \pm 9.58$ & $29.20 \pm 8.59$ & $21.03 \pm 5.88$ & $16.36 \pm 5.04$ & $17.44 \pm 4.89$ & $8.87 \pm 2.60$ & $12.79 \pm 3.56$ & $140.07 \pm 38.86$ & $47.06 \pm 12.32$ \\
\hline & T value* & 0.853 & 0.881 & 0.437 & 0.532 & 1.356 & 1.082 & 0.175 & 0.529 & 10.154 \\
\hline & $p$ & 0.395 & 0.380 & 0.663 & 0.596 & 0.177 & 0.281 & 0.862 & 0.598 & 0.000 \\
\hline \multirow[t]{4}{*}{ Recreation* } & Yes & $34.42 \pm 9.25$ & $29.33 \pm 8.13$ & $21.49 \pm 5.63$ & $16.70 \pm 4.97$ & $17.32 \pm 4.75$ & $8.82 \pm 2.63$ & $12.93 \pm 3.28$ & $141.04 \pm 37.32$ & $42.17 \pm 13.26$ \\
\hline & No & $23.50 \pm 11.63$ & $17.75 \pm 10.56$ & $14.00 \pm 7.36$ & $12.00 \pm 6.96$ & $12.25 \pm 6.34$ & $6.37 \pm 3.54$ & $8.87 \pm 4.76$ & $94.75 \pm 48.26$ & $27.37 \pm 4.98$ \\
\hline & \begin{tabular}{|l} 
T value* \\
\end{tabular} & 3.229 & 3.886 & 3.629 & 2.569 & 2.910 & 2.537 & 3.349 & 3.387 & 3.1393 .139 \\
\hline & $\mathrm{p}$ & 0.001 & 0.000 & 0.000 & 0.011 & 0.004 & 0.012 & 0.001 & 0.001 & 0.002 \\
\hline \multirow[t]{4}{*}{ Chat } & Yes & $35.07 \pm 8.11$ & $30.10 \pm 7.26$ & $22.21 \pm 4.88$ & $17.27 \pm 4.60$ & $18.02 \pm 3.88$ & $8.96 \pm 2.44$ & $13.35 \pm 2.79$ & $145.00 \pm 32.55$ & $44.51 \pm 13.11$ \\
\hline & No & $32.96 \pm 10.66$ & $27.71 \pm 9.43$ & $20.25 \pm 6.53$ & $15.83 \pm 5.50$ & $16.30 \pm 5.56$ & $8.51 \pm 2.92$ & $12.24 \pm 3.86$ & $133.83 \pm 43.13$ & $38.93 \pm 13.08$ \\
\hline & T valu & 1.482 & 1.899 & 2.264 & 1.893 & 2.384 & 1.131 & 2.191 & 1.952 & 2.874 \\
\hline & $p$ & 0.140 & 0.059 & 0.025 & 0.060 & 0.018 & 0.260 & 0.030 & 0.052 & 0.005 \\
\hline \multirow{4}{*}{$\begin{array}{l}\text { Knowledge } \\
\text { acquisition }\end{array}$} & Yes & $35.45 \pm 6.43$ & $29.77 \pm 6.95$ & $23.02 \pm 3.68$ & $17.95 \pm 4.24$ & $17.42 \pm 3.77$ & $9.02 \pm 2.31$ & $13.55 \pm 1.51$ & $146.20 \pm 26.94$ & $30.20 \pm 7.50$ \\
\hline & No & $33.52 \pm 10.28$ & $28.55 \pm 8.95$ & $20.64 \pm 6.29$ & $16.09 \pm 5.31$ & $17.01 \pm 5.20$ & $8.63 \pm 2.81$ & $12.53 \pm 3.79$ & $137.01 \pm 41.47$ & $44.69 \pm 12.91$ \\
\hline & \begin{tabular}{|l} 
T value* \\
\end{tabular} & 1.123 & 0.793 & 2.284 & 2.029 & 0.466 & 0.800 & 1.648 & 1.324 & 6.778 \\
\hline & $p$ & 0.263 & 0.429 & 0.024 & 0.044 & 0.642 & 0.425 & 0.101 & 0.187 & 0.000 \\
\hline \multirow{4}{*}{$\begin{array}{l}\text { Navigating } \\
\text { sites }\end{array}$} & Yes & $35.94 \pm 7.27$ & $30.74 \pm 7.38$ & $22.76 \pm 4.86$ & $17.76 \pm 4.46$ & $18.37 \pm 4.06$ & $9.15 \pm 2.35$ & $13.84 \pm 2.57$ & $148.58 \pm 31.74$ & $46.52 \pm 13.49$ \\
\hline & No & $33.17 \pm 10.27$ & $28.08 \pm 8.88$ & $20.54 \pm 6.15$ & $16.01 \pm 5.32$ & $16.61 \pm 5.14$ & $8.55 \pm 2.83$ & $12.34 \pm 3.65$ & $135.32 \pm 40.82$ & $39.59 \pm 12.83$ \\
\hline & T value* & 1.759 & 1.900 & 2.310 & 2.080 & 0.189 & 1.352 & 2.687 & 2.088 & 3.228 \\
\hline & $p$ & 0.080 & 0.059 & 0.022 & 0.039 & 0.030 & 0.178 & 0.008 & 0.038 & 0.001 \\
\hline \multirow{4}{*}{$\begin{array}{l}\text { Exposure to } \\
\text { violence }\end{array}$} & Yes & $37.14 \pm 5.84$ & $31.83 \pm 5.14$ & $22.70 \pm 3.68$ & $17.68 \pm 3.37$ & $18.91 \pm 3.07$ & $9.54 \pm 1.70$ & $13.87 \pm 2.06$ & $151.70 \pm 23.25$ & $52.37 \pm 7.15$ \\
\hline & No & $30.33 \pm 11.56$ & $25.43 \pm 10.24$ & $19.43 \pm 7.30$ & $15.17 \pm 6.36$ & $15.05 \pm 5.76$ & $7.79 \pm 3.29$ & $11.50 \pm 4.19$ & $124.72 \pm 47.28$ & $29.30 \pm 6.22$ \\
\hline & \begin{tabular}{|l} 
T value* \\
\end{tabular} & 5.109 & 5.435 & 3.887 & 3.380 & 5.738 & 4.603 & 4.944 & 4.982 & 23.133 \\
\hline & $\mathrm{p}$ & 0.000 & 0.000 & 0.000 & 0.000 & 0.000 & 0.000 & 0.000 & 0.000 & 0.000 \\
\hline
\end{tabular}


Yayan, E. H., Dağ, Y. S., Düken, M. E., \& Ulutaş, A. (2019). Investigation of relationship between smartphone addiction and internet addiction in working children in industry. Journal of Human Sciences, 16(1), 143-154. doi:10.14687/ihs.v16i1.5397

In our study, the Internet addiction scale scores, the smartphone addiction scale scores and their sub-scale score averages were examined. The Internet and smartphone addiction scales and their sub-scales were compared according to some demographic characteristics of the students. According to the analysis made based on paternal vital status, the average phone addiction sub-scale score and Internet addiction score was higher in children with deceased fathers, with a significant difference between the groups. The same phenomenon is seen when the mother is not alive, and it is observed that the children who have deceased mothers took higher addiction scores. According to the analysis made based on the Internet supervision, the average score was found to be higher in children whose Internet use has not been supervised, and the difference between the groups was significant.

Their addiction was investigated according to the relationship with their masters in the workplace. It was observed that the total smartphone addiction score and the mean tolerance, withdrawal symptoms, overuse, physical symptoms sub-scale scores of the smartphone addiction scale and the mean Internet addiction sub-scale score were found to differ significantly between the groups, and that the score averages of children who reported a good relationship with their masters were found to be lower.

It was determined that the education status of children was not effective on smartphone addiction and its sub-scales, but it was important in Internet addiction with a significant difference between the groups. It was found that particularly the children who do attend school have higher Internet addiction scores (Table 2).

The addiction scores of children were compared according the way the use smartphones and the Internet. Although there was no difference in the average smartphone addiction scores of children who use them for educational purposes, the Internet addiction scores of those who use Internet for educational purposes were significantly lower. Addiction scores were high in all areas in children who use them for entertainment purposes. For children using it for chatting purposes, the mean Internet addiction scores were found to be higher in positive expectation, excessive use and physical symptoms sub-scales. Positive expectations, cyberspace-oriented relationship and Internet addiction scores in children using it for information purposes were found to be significantly higher. In the use for site navigation purposes, however, cyberspace-oriented relationship, overuse, physical symptoms, smartphone addiction and Internet addiction scores were found to be significantly higher. Whether the children are exposed to violence due to their work was investigated and the effect of this on addiction scores was examined. It was found that children who had been exposed to violence have significantly higher addiction scores with a statistically significant difference (Table 2).

Table 3. Relationship between Internet Addiction Scale and Smartphone Addiction Scale

\begin{tabular}{lcc}
\hline SAS & & $\mathrm{IAS}$ \\
\hline Daily-life disturbance and tolerance & & $\mathrm{0.430^{** }}$ \\
\cline { 2 - 3 } (tolerance) & $\mathrm{p}$ & $\mathbf{0 . 0 0 0}$ \\
\hline Withdrawal symptoms & $\mathrm{r}$ & $\mathbf{0 . 4 7 4 ^ { * * }}$ \\
\cline { 2 - 3 } & $\mathrm{p}$ & $\mathbf{0 . 0 0 0}$ \\
\hline Positive anticipation & $\mathrm{r}$ & $\mathbf{0 . 3 7 3 ^ { * * }}$ \\
\hline Cyberspace-oriented relationship & $\mathrm{p}$ & $\mathbf{0 . 0 0 0}$ \\
\hline Overuse & $\mathrm{r}$ & $\mathbf{0 . 3 8 2 ^ { * * }}$ \\
\hline Social network addiction & $\mathrm{p}$ & $\mathbf{0 . 0 0 0}$ \\
\cline { 2 - 3 } & $\mathrm{r}$ & $\mathbf{0 . 4 6 5 ^ { * * }}$ \\
\hline Physical symptoms & $\mathrm{p}$ & $\mathbf{0 . 0 0 0}$ \\
\cline { 2 - 3 } & $\mathrm{r}$ & $\mathbf{0 . 4 2 0 ^ { * * }}$ \\
\hline
\end{tabular}


Yayan, E. H., Dağ, Y. S., Düken, M. E., \& Ulutaş, A. (2019). Investigation of relationship between smartphone addiction and internet addiction in working children in industry. Journal of Human Sciences, 16(1), 143-154. doi:10.14687/jhs.v16i1.5397

\begin{tabular}{lcc}
\hline Phone addiction & $\mathrm{r}$ & $\mathbf{0 . 4 4 0 ^ { * * }}$ \\
\cline { 2 - 3 } & $\mathrm{p}$ & $\mathbf{0 . 0 0 0}$ \\
\hline $\mathrm{P}<0.001$ Bivariate Correlate & & \\
\hline
\end{tabular}

The relationship between smartphone addiction and Internet addiction in working children was investigated. There was a strong positive correlation between the daily-life disturbance and tolerance, withdrawal symptoms, overuse, social network addiction sub-scales of the Smartphone Addiction Scale and phone addiction scale. A positive and moderate relationship was observed between positive anticipation, physical symptoms and cyberspace-oriented relationship sub-scales of the smartphone addiction scale and phone addiction scale (Table 3).

\section{Discussion}

Today, many problems have emerged due to the increasing use and easier accessibility of the Internet and smartphones in adolescents (Nie et al., 2017). Studies reported many psychosocial problems, addiction in particular (Dhir, Chen, \& Nieminen, 2015; Sasmaz et al., 2014; Stavropoulos, Alexandraki, \& Motti-Stefanidi, 2013). Considering the research findings, it was determined that children whose parents are not alive have higher levels of smartphone and Internet addiction. Considering the literature review, children with poor relationships who had no support from their parents, friends, teachers and environment were found to have higher Internet addiction (Chen, Li, \& Li-Liang, 2007; Lee \& Lee, 2017; Tichon \& Shapiro, 2003; Zhu, Zhang, Yu, \& Bao, 2015).

Relationship between Internet addiction and individual, familial and environmental factors have been shown recently (Wu et al., 2016). In our study, the children who had uncontrolled Internet use found to have significantly higher addiction scores. Studies revealed that Internet addiction is related to parental control, and it is also seen in our study that adolescents controlled in a similar had lower addiction scores (Floros, Siomos, Fisoun, \& Geroukalis, 2013; Grant \& Kim, 2002; Wu et al., 2016).

In our study, it was observed that the children who stated better relationships with their master at the workplace had lower average scores. The masters of children at workplace is an important figure in their life, and they assume the combined roles of parents, peers and teachers. According to the relevant literature review, there are no studies that investigate children's level of addiction and relationships with their masters. Considering the level of parent-child bond, however, researchers have found that a high-level of father-child trust leads to a low level of Internet addiction in adolescents, and that mother-child alienation has a positive correlation with the problematic behavior of young people (Deng, Fang, Wu, Zhang, \& Liu, 2013). It was also found that a weak parent-child bond is a risk factor contributing to the addictive online behavior of children (Li Lei \& Wu, 2007; Luo \& Peng, 2008). Moreover, several studies have investigated the role of peer bonds in Internet addiction in young people, and reported that the quality of peer bonds contributes to the Internet addiction of adolescents (L. Lei \& Wu, 2009; Li, Garland, \& Howard, 2014). In another study, a significant correlation has been found between the Internet addiction and mother-child, father-child and peer bonds (Yang, Zhu, Chen, Song, \& Wang, 2016).

Studies have shown that adolescents whose school life is satisfactory are less likely to develop Internet addiction (Y.-R. Kweon \& Kim, 2014; Rehbein \& Baier, 2013). Kweon and Park (2012) have reported that adoption of school rules and having good relations with peers and teachers are an important protective factor against Internet addiction in children (Kweon \& Park, 2012). In our study, children who don't go to school, despite being at the school age, had higher Internet addiction scores in line with the literature. 
Yayan, E. H., Dağ, Y. S., Düken, M. E., \& Ulutaş, A. (2019). Investigation of relationship between smartphone addiction and internet addiction in working children in industry. Journal of Human Sciences, 16(1), 143-154. doi:10.14687/jhs.v16i1.5397

In our study, in which children's use of smartphones and the Internet were investigated, it was found that the mean smartphone and Internet addiction scores were higher in children who use them for entertainment, chatting and site navigation purposes. Current research has shown that adolescents who are inclined to online gaming are more likely to be Internet addicts (Wu et al., 2016). Canbaz et al. (2009) found that the mostly performed activity on a computer was Internet use and that most of the online behavior was about information and conversation (Canbaz, Sunter, Peksen, \& Canbaz, 2009). The reasons why children use the Internet for entertainment, chatting, and site navigation may be that the adolescents do not have adequate communication in the working environment, and that they satisfy this deficiency on the Internet environment (Byun et al., 2009; Huan, Ang, \& Chye, 2014).

When we examined addiction scores according to whether children were exposed to violence in workplaces, we found that children who experienced violence had significantly higher scores in all areas of the scales. In his study, Aksakal (2016) has found that a significant number of children who work as apprentices at workplaces have experienced violence many times (Aksakal, 2016). In the same way, Bilgin (2009) found that children working in streets are exposed to sexual, physical and emotional violence and that children became increasingly prone to crime (Bilgin, 2009). There are no studies investigating the violence experienced by working children and their Internet and mobile phone addiction. However, some studies show that children experiencing social phobia, loneliness and depression are more dependent on virtual environment. This is because the children feel happier and free in the virtual environment (Yayan, Arikan, Saban, Gürarslan Baş, \& Özel Özcan, 2017). For this reason, the children who exposed the violence may spend more time on the Internet and on the smartphone and exhibit addictive behavior for similar reasons such as being happy, feeling free, expressing themselves, receiving social-emotional support. The most important contribution of this study to the literature is the reporting of Internet and phone addiction behaviors of children who are exposed to violence.

In his study that investigates the year-by-year relationship between Internet addiction and smartphone addiction in adolescents between 2011 and 2014, Jun found that Internet and smartphone addiction has increased steadily mutually between 2011 and 2014 (Jun, 2015). Similarly, in our research that investigates the relationship between smartphone addiction and Internet addiction, a correlation was found between Internet addiction and smartphone addiction. In this case, it can be said that both the Internet and telephone addiction rates may have increased year by year due to the presence of Internet connections on their smartphones in recent years.

\section{Conclusions and Recommendations}

In this study, the addiction scores of children whose mothers or fathers are not alive and whose Internet use is not supervised were found to be higher. At the same time, it was also concluded that children are exposed to violence in their working environment, the number of children with good relations with their masters was low, and they use Internet and smartphones for entertainment, chatting and site navigation purposes, which in turn increases addictive behavior.

Working children in industry should be supported by their parents, families and social circles, and addictive behaviors of children should be investigated by carrying out further studies on their working environments and addiction behaviors. At the same time, it is recommended to conduct projects that support working children in psycho-social aspects. 
Yayan, E. H., Dağ, Y. S., Düken, M. E., \& Ulutaş, A. (2019). Investigation of relationship between smartphone addiction and internet addiction in working children in industry. Journal of Human Sciences, 16(1), 143-154. doi:10.14687/ihs.v16i1.5397

\section{References}

Agbo, M. C. (2017). The Health and Educational Consequences of Child Labour in Nigeria. Health Science Journal, 11(1).

Aksakal, E. (2016). Çalssan çocuklar ve sorunlar: İstanbul örneği (Working children and their problems: The Case of Istanbul). Karadeniz Teknik Üniversitesi.

Bilgin, R. (2009). Diyarbakır'da Sokakta Çalışan Çocuklar Üzerine Sosyolojik Bir Araştırma (A Sociological Research on Children Working in the Street in Diyarbakir). Sosyal Bilimler Dergisi, 8(27), 232-244.

Byun, S., Ruffini, C., Mills, J. E., Douglas, A. C., Niang, M., Stepchenkova, S., ... Blanton, M. (2009). Internet Addiction: Metasynthesis of 1996-2006 Quantitative Research. CyberPsychology \& Behavior, 12(2), 203-207. https://doi.org/10.1089/cpb.2008.0102

Canbaz, S., Sunter, T. A., Peksen, Y., \& Canbaz, M. (2009). Prevalence of the Pathological Internet Use in a Sample of Turkish School Adolescents. Iranian J Publ Health, 38(4), 64-71.

Chen, X., Li, F.-H., \& Li-Liang, L. (2007). Prospective Study on the Relationship on between Social Support and Internet Addiction. Chinese Mental Health Journal, 21(4).

Demirci, K., Orhan, H., Demirdas, A., Akpinar, A., \& Sert, H. (2014). Validity and Reliability of the Turkish Version of the Smartphone Addiction Scale in a Younger Population. Klinik Psikofarmakoloji Bülteni-Bulletin of Clinical Psychopharmacology, 24(3), 226-234. https://doi.org/10.5455/bcp.20140710040824

Deng, L. Y., Fang, X. Y., Wu, M. M., Zhang, J. T., \& Liu, Q. X. (2013). Family environment, parent-Child attachment and adolescent Internet addiction. Psychol. Dev. Educ., 3, 305-311.

Dhir, A., Chen, S., \& Nieminen, M. (2015). Predicting adolescent Internet addiction: The roles of demographics, technology accessibility, unwillingness to communicate and sought Internet gratifications. Computers in Human Bebavior, 51, 24-33. https://doi.org/10.1016/j.chb.2015.04.056

Fidan, F. (2004). Çalışan Çocuk Olgusuna Sosyo-Psikolojik Bakış (Psychological and Social Aspects of the Child Labor Question ). Trakya Üniversitesi Sosyal Bilimler Dergisi, 4(1), 30-49.

Floros, G. D., Siomos, K., Fisoun, V., \& Geroukalis, D. (2013). Adolescent Online Gambling: The Impact of Parental Practices and Correlates with Online Activities. Journal of Gambling Studies, 29(1), 131-150. https://doi.org/10.1007/s10899-011-9291-8

Gol, I. (2016). Evaluation of working conditions and perceptions of health status and the importance of health in child and young workers in the industrial site. TAF Preventive Medicine Bulletin, 15(4), 347. https://doi.org/10.5455/pmb.1-1454417875

Grant, J. E., \& Kim, S. W. (2002). No Title. Psychiatric Quarterly, 73(3), 239-247. https://doi.org/10.1023/A:1016044906341

Gunuc, S., \& Dogan, A. (2013). The relationships between Turkish adolescents' Internet addiction, their perceived social support and family activities. Computers in Human Behavior, 29(6), 21972207. https://doi.org/10.1016/j.chb.2013.04.011

Huan, V. S., Ang, R. P., \& Chye, S. (2014). Loneliness and Shyness in Adolescent Problematic Internet Users: The Role of Social Anxiety. Child \& Youth Care Forum, 43(5), 539-551. https://doi.org/10.1007/s10566-014-9252-3

ILO, I. L. O. (2010). World of Work Report 2010.

IWS, I. W. S. (2017). Internet in Europe Stats.

İşeri, B., Sözen, G., Melik, Ö., Yavaşcan, Ö., Başkesen, A., Çoker, I., \& Yaprak, I. (2005). Çalışan Çocuk; Sosyo-Kültürel Özelikler ve Sağlık Taraması - İzmir Otomotiv Sanayi (Occupational Child; Sociocultural Characteristics and Health Survey-Automotive lndustry in lzmir ). İzmir Tepecik Eğitim Hastanesi Dergisi, 15(1), 45-56.

Jun, W. (2015). An Analysis Study on Correlation of Internet Addiction and Smartphone Addiction of Teenagers. In Information Science and Security (ICISS) 2nd International (pp. 1-3). 
Yayan, E. H., Dağ, Y. S., Düken, M. E., \& Ulutaş, A. (2019). Investigation of relationship between smartphone addiction and internet addiction in working children in industry. Journal of Human Sciences, 16(1), 143-154. doi:10.14687/ihs.v16i1.5397

Kim, D., Lee, Y., Lee, J., Nam, J. K., \& Chung, Y. (2014). Development of Korean Smartphone Addiction Proneness Scale for Youth. PLoS ONE, 9(5), e97920. https://doi.org/10.1371/journal.pone.0097920

Ko, C.-H., Yen, J.-Y., Yen, C.-F., Chen, C.-S., \& Chen, C.-C. (2012). The association between Internet addiction and psychiatric disorder: A review of the literature. European Psychiatry, 27(1), 1-8. https://doi.org/10.1016/j.eurpsy.2010.04.011

Kutlu, M., Savci, M., Demir, Y., \& Aysan, F. (2016). Turkish adaptation of Young's Internet Addiction Test-Short Form: a reliability and validity study on university students and adolescents. Anatolian Journal of Psychiatry, 17(1), 69. https://doi.org/10.5455/apd.190501

Kweon, Y.-R., \& Kim, S.-Y. (2014). Predictors of Protective Factors for Internet Game Addiction in Middle School Students using Data Mining Decision Tree Analysis. Journal of Korean Academy of Psychiatric and Mental Health Nursing, 23(1), 12. https://doi.org/10.12934/jkpmhn.2014.23.1.12

Kweon, Y. R., \& Park, M. S. (2012). Effects of School Adjustment on Higher Grade Elementary School Students' Internet Game Addiction: Focused on Gender Difference. Journal of Korean Academy of Psychiatric and Mental Health Nursing, 21(2), 99. https://doi.org/10.12934/jkpmhn.2012.21.2.99

Kwon, M., Lee, J.-Y., Won, W.-Y., Park, J.-W., Min, J.-A., Hahn, C., ... Kim, D.-J. (2013). Development and Validation of a Smartphone Addiction Scale (SAS). PLoS ONE, 8(2), e56936. https://doi.org/10.1371/journal.pone.0056936

Lee, C., \& Lee, S.-J. (2017). Prevalence and predictors of smartphone addiction proneness among Korean adolescents. Children and Youth Services Review, 77, 10-17. https://doi.org/10.1016/j.childyouth.2017.04.002

Lei, L., \& Wu, L. (2009). Adolescents peer attachment and their internet use. Studies of Psychology and Behavior, 7(2), 81-86.

Lei, L., \& Wu, Y. (2007). Adolescents' Paternal Attachment and Internet Use. CyberPsychology \& Behavior, 10(5), 633-639. https://doi.org/10.1089/cpb.2007.9976

Li, W., Garland, E. L., \& Howard, M. O. (2014). Family factors in Internet addiction among Chinese youth: A review of English- and Chinese-language studies. Computers in Human Behavior, 31, 393-411. https://doi.org/10.1016/j.chb.2013.11.004

Luo, H., \& Peng, Y. (2008). Relationship of Internet addiction and family environment and attachment of the youth. Chin J Clin Psychol, 16(3), 319-321.

Luparenko, S. (2014). The Negative Influence Of The Technical Means On Children's Development. Bulgarian Journal of Science and Education Policy (BJSEP), 8(1), 70-85.

Morahan-Martin, J., \& Schumacher, P. (2000). Incidence and correlates of pathological Internet use among college students. Computers in Human Behavior, 16(1), 13-29. https://doi.org/10.1016/S0747-5632(99)00049-7

Nie, J., Zhang, W., \& Liu, Y. (2017). Exploring depression, self-esteem and verbal fluency with different degrees of internet addiction among Chinese college students. Comprehensive Psychiatry, 72, 114-120. https://doi.org/10.1016/j.comppsych.2016.10.006

Rehbein, F., \& Baier, D. (2013). Family-, Media-, and School-Related Risk Factors of Video Game Addiction. Journal of Media Psychology, 25(3), 118-128. https://doi.org/10.1027/1864$1105 / \mathrm{a} 000093$

Sasmaz, T., Oner, S., Kurt, A. O., Yapici, G., Yazici, A. E., Bugdayci, R., \& Sis, M. (2014). Prevalence and risk factors of Internet addiction in high school students. The European Journal of Public Health, 24(1), 15-20. https://doi.org/10.1093/eurpub/ckt051

Stavropoulos, V., Alexandraki, K., \& Motti-Stefanidi, F. (2013). Recognizing internet addiction: Prevalence and relationship to academic achievement in adolescents enrolled in urban and rural Greek high schools. Journal of Adolescence, 36(3), 565-576. https://doi.org/10.1016/j.adolescence.2013.03.008 
Yayan, E. H., Dağ, Y. S., Düken, M. E., \& Ulutaş, A. (2019). Investigation of relationship between smartphone addiction and internet addiction in working children in industry. Journal of Human Sciences, 16(1), 143-154. doi:10.14687/ihs.v16i1.5397

Şata, M., Çelik, İ., Eetürk, Z., \& Taş, U. E. (2016). Akıllı Telefon Bağımlılığ1 Ölçeği’nin (ATBÖ) Türk Lise Öğrencileri İçin Uyarlama Çalışması. Eğitimde ve Psikolojide Ölçme ve Değerlendirme Dergisi, 7(1). https://doi.org/10.21031/epod.95432

Tahiroğlu, A. Y., Çelik, G. G., Bahalı, K., \& Avc1, A. (2010). Medyanın Çocuk ve Gençler Üzerine Olumsuz Etkileri; Şiddet Eğilimi ve İnternet Bağımlı̆̆1 (Negative Effects of Excessive Media Exposure in Children and Adolescents; Violence Tendency and Internet Dependence). Yeni Symposium, 48(1), 19-30.

Tang, J., Yu, Y., Du, Y., Ma, Y., Zhang, D., \& Wang, J. (2014). Prevalence of internet addiction and its association with stressful life events and psychological symptoms among adolescent $\begin{array}{llll}\text { internet users. } \quad \text { Addictive } & \text { Behaviors, }\end{array}$ https://doi.org/10.1016/j.addbeh.2013.12.010

Tichon, J. G., \& Shapiro, M. (2003). The Process of Sharing Social Support in Cyberspace. CyberPsychology \& Behavior, 6(2), 161-170. https://doi.org/10.1089/109493103321640356

Tor, H. (2010). Status of Child Labor in Turkey. Journal of World of Turks, 2(2), 25-42.

Tsitsika, A. K., Andrie, E. K., Psaltopoulou, T., Tzavara, C. K., Sergentanis, T. N., NtanasisStathopoulos, I., ... Tsolia, M. (2016). Association between problematic internet use, sociodemographic variables and obesity among European adolescents. The European Journal of Public Health, 26(4), 617-622. https://doi.org/10.1093/eurpub/ckw028

TÜIK. (2011). Turkey Statistical Institute Report, 2011.

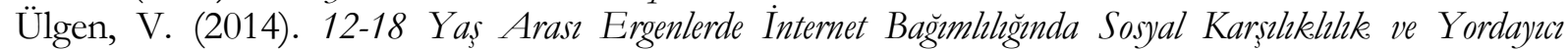
Faketörlerin Değerlendirilmesi (Assessment of Social Reciprocity and Predictors of Internet Addiction in 1218 Years Old Adolescents). Marmara Üniversitesi.

Wu, X.-S., Zhang, Z.-H., Zhao, F., Wang, W.-J., Li, Y.-F., Bi, L., ... Sun, Y.-H. (2016). Prevalence of Internet addiction and its association with social support and other related factors among adolescents in China. Journal of Adolescence, 52, 103-111. https://doi.org/10.1016/j.adolescence.2016.07.012

Yang, X., Zhu, L., Chen, Q., Song, P., \& Wang, Z. (2016). Parent marital conflict and Internet addiction among Chinese college students: The mediating role of father-child, mother-child, and peer attachment. Computers in Human Bebavior, 59, 221-229. https://doi.org/10.1016/j.chb.2016.01.041

Yayan, E. H., Arikan, D., Saban, F., Gürarslan Baş, N., \& Özel Özcan, Ö. (2017). Examination of the Correlation Between Internet Addiction and Social Phobia in Adolescents. Western Journal of Nursing Research, 39(9), 1240-1254. https://doi.org/10.1177/0193945916665820

Yıldırım, B., Beydili, E., \& Görgülü, M. (2015). The Effects of Education System on to the Child Labour: An Evaluation from the Social Work Perspective. Procedia - Social and Behavioral Sciences, 174, 518-522. https://doi.org/10.1016/j.sbspro.2015.01.697

Zhu, J., Zhang, W., Yu, C., \& Bao, Z. (2015). Early adolescent Internet game addiction in context: How parents, school, and peers impact youth. Computers in Human Behavior, 50, 159-168. https://doi.org/10.1016/j.chb.2015.03.079 